\title{
STUDY OF PHYSICO-CHEMICAL PARAMETERS OF WATER SAMPLE OF MAHAL AREA OF NAGPUR CITY
}

\author{
Ekta R Raut \\ Department of Chemistry \\ G H Raisoni College of Engineering, Nagpur, \\ Maharashtra, India
}

\begin{abstract}
About $71 \%$ of the earth's surface is covered by water, the balance of the ecosystem is predicated by its inter-dependence on the water cycle. All living cells need water and water is the biggest differentiation of our planet with other planets. The importance of water becomes more conspicuous when considering the part it plays in the survival of humans. According to H.H. Mitchell in the Journal of Biological Chemistry, the brain and heart consists of about $73 \%$ of water, the lungs is made up of $83 \%$ water, the skin consists of $64 \%$ water, the muscles and kidneys are made of $79 \%$ of water and the bones of $63 \%$ water. This goes to show how studying the physiochemical properties of domestic water is important as highlighted in this paper. Proper study of the physiochemical properties of water from various regions of Nagpur with special outlook at the region of Mahal gives us insight into the quality of life and health in this region, as the quality of water can be directly proportional to the quantity of life, based on the fact of the percentage of water in all essential systems of the body. By studying these parameters the researchers have been able to identify regions with poor quality water, proffered systemic treatments as well as advice on how to ameliorate the situation in those regions.
\end{abstract}

Keywords- Alkalinity, Dissolved Oxygen, pH, water quality, Mahal

\section{INTRODUCTION}

Nagpur is a beautiful city lying $21.145^{\circ} \mathrm{N}, 79.0882^{\circ} \mathrm{E}$ of the equator [1], situated at the central belt of India, spanning an area mass of about 87.78 meter square, noted for its spectacular lakes and parks, this region remains a home of spectacle and research. Nagpur is home to about 42 localities, but in the context of this

\author{
Aruna M Sudame \\ Department of Chemistry \\ G H Raisoni College of Engineering, Nagpur, \\ Maharashtra, India
}

research we are considering one of the most prominent locality the Mahal region to research about some physiochemical parameter of domestic water in this area. Mahal remains one of the oldest localities in Nagpur, a visit to Mahal will immediately reveal her proximity to the Nag River, a primary source of water to the inhabitants of this region. Water has always been a primary source of life for all living organisms, and the people of Mahal are no exception to the tremendous importance of water in their daily life.

Doing a cultural observation of the Mahal area, water is being used for several activates in this region, it plays a pivotal routine in the life of ordinary people there. Water is used for human consumption, for food preparation, washing and cleaning, it is of everyday importance to the agricultural landscape and relevance of which this region is known for, animal consumption, recreation and water even has some religious and spiritual significance in this region.[2] Considering the importance of water to this people we are going to be engaging some scientific methods to discover the quality of water available in this region, this will be done in comparison with the World Health Organization (WHO) standard measurement for different parameters of water in this region, we will highlight the important metrics, identify the functional parameters and highlight the areas that are dysfunctional, the defect it has on the inhabitants and some simple preventive or treatment measures.

\section{METHODOLOGY}

In this research we take a look at the major source of water for domestic use in the Mahal region and we identified the following water samples:

(i) Well water

(ii) Tube well water

(iii) R.O water 
(iv) Tap water.

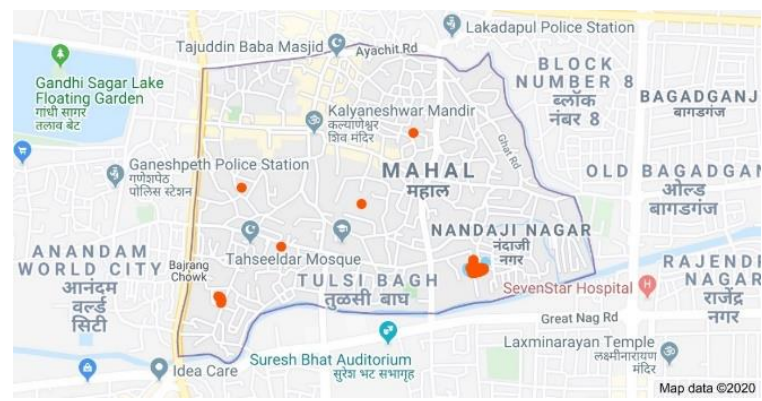

The red spot indicates locations where our water samples were taken

Several samples of this water was taken from different locations in Mahal and brought to the laboratory for analysis under certain laid out parameters, this samples were not all taken from one location, so it is okay to say that our report represents the average case of the physiochemical property of water in the Mahal region. Several experiments including complexometric and Argentometric titrations have been done for these water samples, and the result gives us more generic and accurate data for this region. Some of the parameters that this water samples were tested on includes:
(i) Temperature
(ii) $\mathrm{pH}$
(iii) Total Alkalinity
(iv) Hardness
(v) Dissolved Oxygen
(vi) Chloride ions

The results of the experiment conducted will be measured against the following World Health Organization (W.H.O) standards for the same parameters. The parameters are tested in our Lab. We used Deluxe $\mathrm{pH}$ Meter-101 for determination of $\mathrm{pH}$ and thermometer for measuring temperature. Alkalinity, Hardness, D.O. and Chloride ion determined by titration method. Alkalinity determination is Neutralization titration, hardness is Complexometric titration, DO is Iodometric titration and chloride ion is Argentometric titration. [11]

\section{EXPERIMENTAL}

Method of Determination

\begin{tabular}{|l|l|}
\hline Temperature & Thermometer \\
\hline $\mathrm{pH}$ & Deluxe $\mathrm{pH}$ Meter-101 \\
\hline Alkalinity & Titration by $\mathrm{HCl}$ \\
\hline Hardness & Titration by EDTA \\
\hline Dissolved Oxygen & Titration by $\mathrm{Na}_{2} \mathrm{~S}_{2} \mathrm{O}_{3}$ \\
\hline
\end{tabular}

\begin{tabular}{|l|l}
\hline Chloride ion & Titration by Silver Nitrate \\
\hline
\end{tabular}

The WHO standards for water in respect to the above stated parameters as listed in the Journal of Chemistry are as follows:

TABLE I

\begin{tabular}{|c|l|l|}
\hline Sr No & Parameter & WHO limits \\
\hline 1 & Temperature & $27^{\circ} \mathrm{C}$ \\
\hline 2 & $\mathrm{pH}$ & 6.5 to 8.5 \\
\hline 3 & Alkalinity & $20-200 \mathrm{mg} / \mathrm{l}$ \\
\hline 4 & Hardness & $\begin{array}{l}0 \text { to } 60 \mathrm{mg} / \mathrm{l}(\mathrm{soft}) \\
61 \text { to } 120 \mathrm{mg} / \mathrm{l} \\
\text { (moderate) } \\
\end{array}$ \\
& & $>121$ (Hard) \\
\hline 5 & D.O & 5 to $9.5 \mathrm{mg} / \mathrm{l}$ \\
\hline 6 & Chloride & $<250 \mathrm{mg} / \mathrm{l}$ \\
\hline
\end{tabular}

The result from our experiment for the sample collected is computed below:

TABLE II

\begin{tabular}{|l|l|l|l|l|}
\hline Parameter & $\begin{array}{l}\text { Tap } \\
\text { Water }\end{array}$ & $\begin{array}{l}\text { R.O } \\
\text { water }\end{array}$ & $\begin{array}{l}\text { Well } \\
\text { Water }\end{array}$ & $\begin{array}{l}\text { Tube } \\
\text { Water }\end{array}$ \\
\hline $\mathrm{pH}$ & 7.0 & 7.2 & 6.2 & 8.2 \\
\hline Hardness (ppm) & 92.00 & 100 & 84 & 104 \\
\hline D.O (mg/l) & 1.44 & 0.4928 & 2.182 & 0.4576 \\
\hline $\begin{array}{l}\text { Chloride (mg/l) } \\
\text { Total Alkalinity } \\
\text { (ppm) }\end{array}$ & 11.9 & 3.99 & 163.94 & 4.1 \\
\hline \begin{tabular}{l} 
Temperature \\
\hline
\end{tabular} & $27.4^{\circ} \mathrm{C}$ & $27.9^{\circ} \mathrm{C}$ & $26.8^{\circ} \mathrm{C}$ & $27.2^{\circ} \mathrm{C}$ \\
\hline
\end{tabular}

\section{RESULT AND DISCUSSION}

From our analysis we discovered that the $\mathrm{pH}$ range of well water in Mahal is quite acidic, it is slightly below the recommended range of limits prescribed by the WHO which is 6.5 to 8.5 . Also, the amount of dissolved oxygen in the well water, tube well water, R.O water and even tap water was below the standards set by WHO, dissolved oxygen is very essential for aquatic life to survive in water, it also adds good taste to the water. However, from this experiment we can conclude that this water is fit for drinking purposes as all the parameters are well within limit set by WHO. 


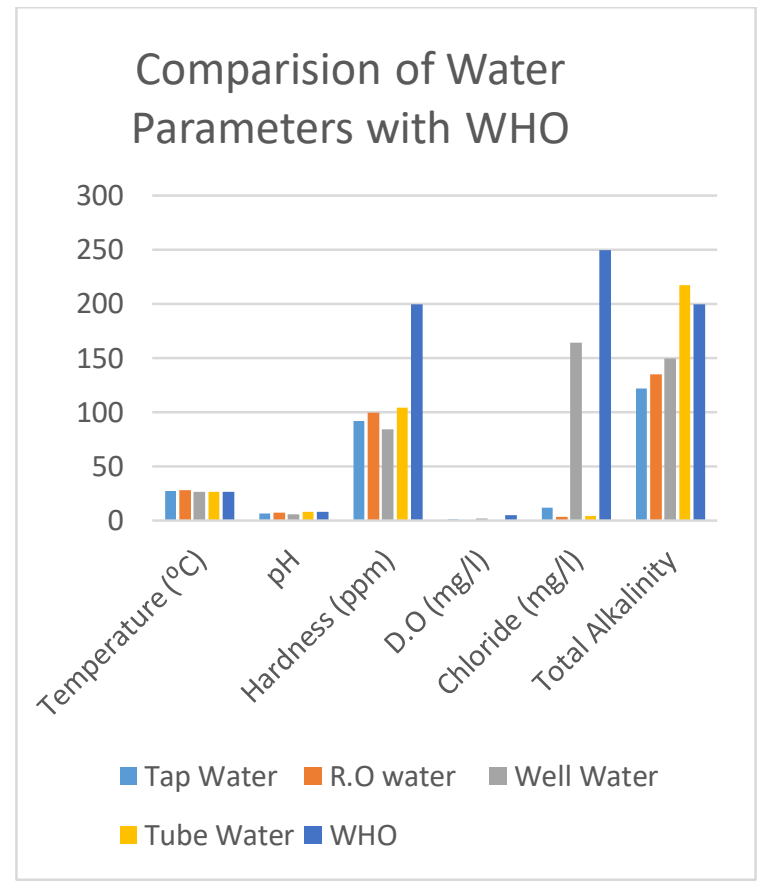

V. CONCLUSION

After an extensive research into the physiochemical parameter of water in the Mahal region we came to the conclusion that the tube water, tap water as well as the R.O water in the region is fit for domestic usage, however we discovered that the well water was too acidic and not fit for domestic usage, as it will be detrimental to health and reactive to other materials, especially metallic parts. Also, considering the low oxygen in her water especially during the summer period, we came to the conclusion that her water would be very suitable for industrial use, because low oxygen means it will reduce corrosion on metallic parts, and low oxygen also makes water not tasty for drinking.

\section{REFERENCES}

[1] https://www.geodatos.net, Geographic coordinates of Nagpur, Maharashtra, India.

[2] Bharti Dattatraya, Ali Sayyad Isub, G. G. Galkwad, D. R. Taikar, J. Dhore, (2011), Physiochemical characteristics of bore well water quality in Nagpur region (South zone), J. Chem. Pharm. Res, (pp:922927).

[3] Standard method for examination of waters and waste, $1985,16^{\text {th }}$ Ed., APHA, AWWA and WPCF Inc. Newyork

[4] Rakesh Kumar, R. D. Singh and K. D. Sharma., (2005), Journal Article-Water resources of India, India Current Science, (pp:794-811).

[5] Abdul A Jameel, Sirajuddin J., (2006), Risk Assessment of Physico-Chemical Contaminants in
Groundwater of Pettavaithalai Area, Tiruchirappalli, Tamilnadu - India, Environmental Monitoring and Assessment, (pp:299-312).

[6] N. R. Prasad and J. M. Patil., (2008), A study of Physico-chemical parameters of Krishna River water particularly in western Maharashtra, Rasayan J. Chem, (pp: 943-958).

[7] M. Chandra Shekhar, (1995), Land use Water Quality Modeling: A Case Study, Journal of water science and technology, (pp: 383-386).

[8] Manual of Standards of Drinking water supply, 2nd special report serial no. 44 ICMR, New Delhi (1975). [9] M. D. Bharathi., Patra Sivaji, S. Sundaramoorthy, P. Madeswaran, A. Sundaramanickam, (2017), "Elucidation of seasonal variations of Physicochemical and biological parameters with statistical analysis methods in Puducherry coastal waters", Marine Pollution Bulletin, 122(1-2).

[10] World Health Organization, www.who.in [11] Guidance Manual for Drinking Water Quality Monitoring and Assessment, first addition, National Environmental Engineering Research Institute, Nagpur.(2007)

[12] BIS 1991: Specification for drinking water IS: 10500: 1991, Bureaa of Indian standard. 